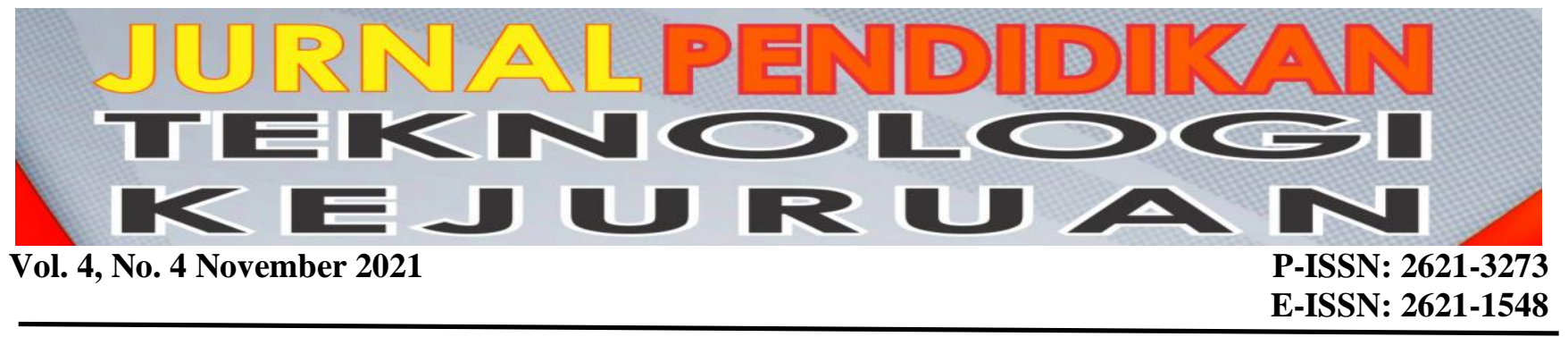

\title{
Evaluation of the Dimensions of the Tsunami Evacuation Path for the Community of Air Tawar Barat Village, North Padang District, Padang City, Based on Geographic Information System (GIS)
}

\author{
Faisal Ashar', Iqbal Maulana Yusup ${ }^{2}$, Fitra Rifwan ${ }^{3}$, Laras Oktavia Adreas ${ }^{4}$ \\ ${ }^{1234}$ Civil Engineering, Faculty of Engineering, Universitas Negeri Padang \\ ${ }^{*}$ Corresponding author, e-mail: iqbalmaulana.y98@gmail.com
}

\begin{abstract}
Air Tawar Barat Village is included in the High-Risk Zone (area with a high level of vulnerability to tsunamis) in Padang City, so very severe damage likely occurs in the event of a tsunami. The characteristics of the tsunami in Padang City are local tsunamis or short-range tsunamis, where the time interval for tsunami arrivals is between 20-30 minutes. Based on these conditions, a tsunami evacuation route is urgently needed by the community. The current evacuation route is still ineffective because the distance that must be covered is $3-5 \mathrm{~km}$ in less than 30 minutes. This study aims to evaluate the evacuation routes that are less effective by comparing the evacuation routes from the government with the results of GIS analysis. The method used in this research is Network Analyst. The results of this study found that the time needed to evacuate was 10 minutes by going to 26 P-TES. Where 24 P-TES are located on the UNP campus, 1 is in the Air Tawar Timur Village and 1 is a planned P-TES. The evacuation route generated from the results of the GIS analysis is more effective than the route from the government because the route to P-TES is closer than having to leave the tsunami zone so that it is more likely to be taken by the community.
\end{abstract}

Keywords: Evaluation of the Evacuation Path, Evacuation Path, Tsunami

\section{INTRODUCTION}

West Sumatra is in a complex geological area because it is located at the collision of two large tectonic plates (the Indo-Australian Plate and the Eurasian plate) so that there is an engineering earthquake center in the Mentawai Regency. In addition, the plate collision also resulted in a magmatic arc which resulted in the occurrence of the Bukit Barisan mountain range and volcanoes (Prima et al., 2020). Based on the history that has occurred, destructive earthquakes have occurred in West Sumatra seven times, including the Singkarak earthquake (1926 and 1943), Pasaman (1977), Solok (2004) Batu Sangkar (2007) occurred twice and in Padang (2009) (Andreas et al., 2020).

Padang City is the capital city of West Sumatra Province which is located in the West Sumatran waters and has a high risk of a tsunami. According to Danhas., (2011) the location of the city of Padang which is on the West Coast of Sumatra, which is directly adjacent to the Indian Ocean and the zone of the active collision of two plates makes the city of Padang one of the cities most prone to tsunami waves (Suryani et al., 2020).
The characteristics of the tsunami in Padang City have tsunami waves that move quickly so that they can be referred to as local tsunamis or short-range tsunamis (Schlurmann et al., 2011). According to Singh (2010), the time interval for the tsunami that hit the Padang coast was about 20-30 minutes, so that the community evacuation time was less than 30 minutes and they had to walk $3-5 \mathrm{~km}$ to get to the tsunami safe zone. Efforts are urgently needed to reduce the impact caused by the earthquake and tsunami.

After the earthquake that occurred in 2009 and the condition of Padang City which is prone to tsunami disasters, the Padang City Government seeks to minimize the losses that will occur (Ashar et al., 2018). These efforts include the availability of evacuation route maps, evacuation route marking boards, evacuation sites in the form of Temporary Evacuation Places (TES), Potential Temporary Evacuation Places (P-TES) and shelters, availability of tsunami disaster information boards, availability of early warning systems and supporting facilities. others in the city of Padang (Anam et al., 2018).

According to Alhadi, (2014), the evacuation routes in the city of Padang are still very slow to add and 
improve, this is proven by the very few routes and the roads designated as evacuation routes that are still too narrow and damaged so that it will hamper community mobility when used during an evacuation. As for places that can be used as evacuation locations, both vertically and horizontally. There are still very few and still not prepared carefully because they are not equipped with public facilities in the form of clean water and toilets. The robustness of the building as a shelter is also in doubt because during the 30 September 2009 earthquake many buildings collapsed, such as the Bumi Minang Hotel, Ambacang Hotel, Andalas Plaza, Basko Mall (Alhadi, 2014).

The capacity of the shelter in Padang City is not sufficient to accommodate all prospective refugees, this is based on the latest data on shelter buildings and the combination of the number of buildings planned by the Marine and Fisheries Service (DKP) and the Tsunami Alert Community (KOGAMI) which is only able to accommodate $75 \%$ of the population in Padang. tsunami inundation area (Kurniawan et al., 2014).

In the city of Padang itself, some areas are included in the High-Risk Zone (areas with a high level of vulnerability to tsunamis), one of which is the District of North Padang (Oktiari \& Manurung, 2010). In addition, the evacuation route in Padang Utara District has a spatial structure that is included in the tsunami hazard, because the road conditions do not meet the requirements as a tsunami evacuation route, where the minimum width is 10 meters. In addition, in terms of route security, it is still very low because there are many trees, electricity poles, telephone poles on the side of the route so that it will endanger the safety of the community during evacuation (Syam \& Syam, 2016).

Air Tawar Barat Village is a village with the largest population in the North of Padang District with a population of 15699 inhabitants with a population density that reaches 14017 people $/ \mathrm{km}^{2}$. Based on the number of residents and the location of the village in the tsunami hazard zone, it is necessary to have a Disaster Risk Reduction (DRR) program that focuses on the community as disaster management actors and actors, especially at the village or sub-district level. This is in line with the Regulation of the Head of the National Disaster Management Agency Number 1 of 2012 concerning General Guidelines for Disaster Resilient Urban Villages.

Based on the observations that the author has made at the research location, the large number of residents in
Air Tawar Barat Village is because in the village there are colleges and schools as well as several hotels. In the campus area in this village, several buildings can be used as P-TES, but quite a lot of local people do not know for sure about the buildings that can be used as P-TES, including the shortest path to the P-TES. In addition, the road access used for activities is not good and small so that it often experiences traffic jams, especially during peak hours (Rifwan et al., 2019). This is known from the comparison that the author made between the evacuation route guidelines set by BNPB and the state of the research location, in this comparison, there is a difference where the minimum width for the path to TES is 7.5 meters while the road at the research location has a width of around 4-5 meters. With the population and knowledge of the surrounding community, it is very likely that during a tsunami disaster many people will not be able to evacuate themselves to a safe place (Takabatake et al., 2017).

Departing from the above problems, it is necessary to do research related to tsunami evacuation route in the Air Tawar Barat village study was written in the title "Tsunami Evacuation Evaluation Paths for People Air Tawar Barat Village District of North Padang Padang-based Geographic Information System (GIS)".

\section{METHOD}

This research was conducted in Air Tawar Barat Village using the Network Analyst method. The data used are secondary data and primary data. Secondary data was obtained from the internet and literature in the form of road network maps, building maps, administrative maps, evacuation maps, population data, and related journals. While the primary data was obtained from the results of a survey in the field in the form of points for the location of evacuation signs, and P-TES location points as well as access to P-TES.

The data that has been collected is then inputted into a computer which is then analysed using the Service Area and Closest Facility. The Service Area is used to determine the P-TES service area based on a road network map that contains the travel time in crossing the road and the direction of the road, resulting in areas that can be accommodated by P-TES within the specified time. As for the Closest Facility, it is used as a method to determine which facility is closer to an object so that the fastest path to the facility is obtained. After the results of the analysis are carried out and a map of the evacuation time and evacuation route is obtained, then a comparison is made with the map made by the government. 


\section{RESULTS}

\section{A. Roads}

Based on data from the Open Street Map (OSM) and the Public Works Agency, it was found that the road data can be seen in Table 1 .

\begin{tabular}{lll}
\multicolumn{3}{c}{ Table 1. Road } \\
\hline $\begin{array}{l}\text { Data Types of Data } \\
\text { from }\end{array}$ & $\begin{array}{l}\text { The Public } \\
\text { Works } \\
\text { Service }\end{array}$ & OSM \\
\hline Road Type & 2 types & 6 types \\
Number of roads & 86 sections & 590 sections \\
Sections longest & $771 \mathrm{~m}$ & $325 \mathrm{~m}$ \\
Shortest & $21 \mathrm{~m}$ & $1.4 \mathrm{~m}$ \\
Section Road width & $4-5 \mathrm{~m}$ & - The \\
\hline
\end{tabular}

road data is then checked in the field, then data that is in accordance with what is in the field is entered into the road shp map by adding a table to the attribute the table so that the Road Network Map is obtained as shown in Figure 1.

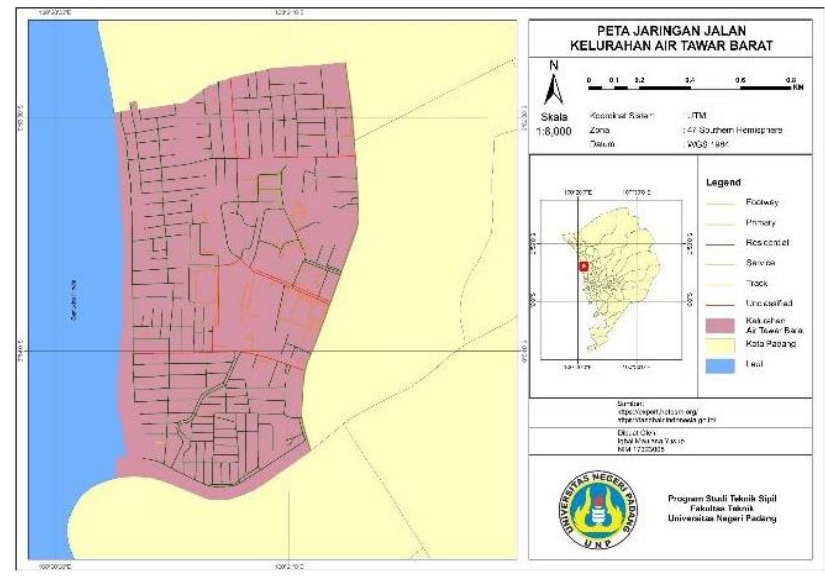

Figure 1. Road Network Map Road

From the Section Map, it can be seen that Residential Roads or Local Roads are the most common roads found in Air Tawar Barat sub-district.

\section{B. Evacuation Signs}

In Air Tawar Barat Village there are 38 evacuation signs, of which there are more signs inside the UNP Campus, namely 23 signs, while outside the UNP Campus there are 15 signs. Based on this number, the signs inside the UNP Campus are closer to each other than those outside the UNP Campus. Comparison of signs can be seen in Table 2 and Figure 2.

Table 2. Differences in

\begin{tabular}{llll}
\multicolumn{4}{l}{ Table 2 . Differences in } \\
\hline Signs & Color & Type & Amount \\
\hline Outside UNP & Orange \& White & 2 & 15 \\
Inside UNP & Green \& White & 3 & 38 \\
\hline
\end{tabular}

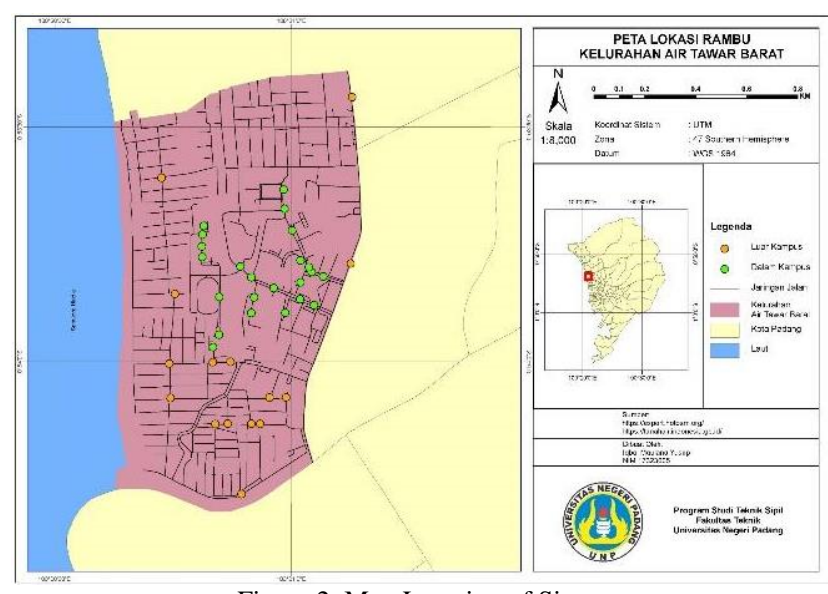

Figure 2. Map Location of Signs

In the field survey, several signs were found that the directions collide with each other between the signs inside the UNP Campus and outside the UNP Campus. It is in front of GOR FIK UNP, where the sign from inside the UNP Campus leads out to Jalan Belibis while the sign from outside the UNP Campus leads into the UNP Campus which leads to the FIK Building. Based on this, of course, the surrounding community will be confused in evacuating between going into or out of the UNP Campus.

\section{Spatial Structure}

Based on the survey results in the field, it shows that in each evacuation route there are several things that can disturb, endanger and hinder the community during the evacuation process. Among them are trees, electricity poles, telkom towers and bridges which in the event of an earthquake are at risk of making evacuation routes cut off. The bridge is the most important thing to pay attention to when evacuating because the Air Tawar Village is split by the flow of water from north to south or from Patenggangan to Muara Sungai. There are 10 bridges in this village with 2 bridges that cannot be passed by vehicles. The two bridges are inside the UNP Campus.

\section{Distribution of P-TES The}

location of the distribution of P-TES in Air Tawar Barat Village was obtained from several journals and survey results directly in the field, so that there were a number of P-TES, namely: Laboratory of the Faculty of Language and Arts, Faculty of Language and Arts, Mining Engineering Building, Faculty of Tourism and Hospitality, Laboratory of the Faculty of Engineering, Hospitality Center, Al-Azhar Mosque, Rectorate and Research Center, Faculty of Education, New Postgraduate Building, Old Postgraduate Building, Faculty of Economics, Integrated Building B, Integrated Building A, UNP Laboratory Development Elementary School, Development 
Junior High School UNP Laboratory, UNP Laboratory Development High School, Psychology Building, Microteaching A (MKU A), Microteaching B (MKU B), UNP Teacher Professional Education (PPG) Building, Integrated Building C, Central Library and Faculty of Sports Science. The P-TES location map can be seen in Figure 3.

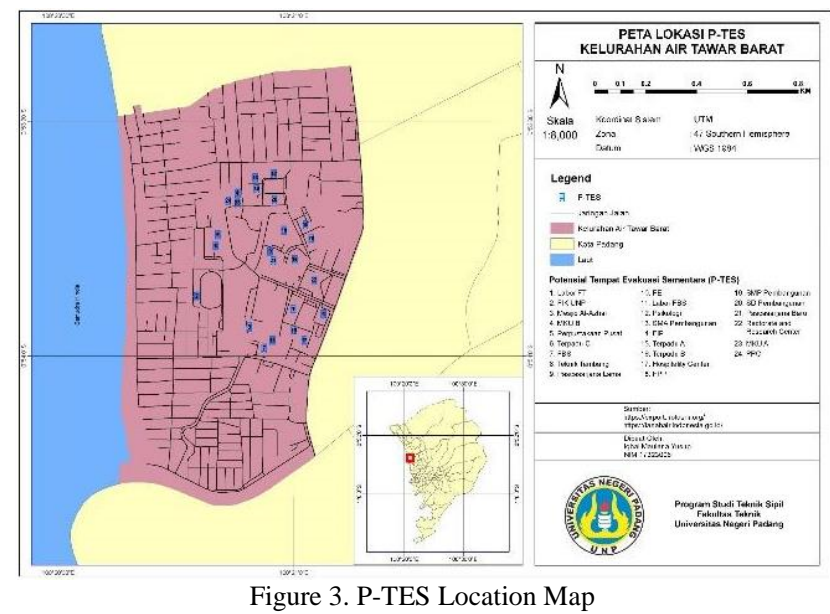

\section{E. Service Area}

Based on the results of the analysis using the service area, all residents in Air Tawar Barat Village can evacuate within 15 minutes by going to P-TES. This is based on the road that can be passed in two directions because people tend to walk during evacuation [12]. Then use the moving speed of the community, which is $1.19 \mathrm{~m} / \mathrm{second}$ [13]. Based on the time the moving speed is then obtained the time in crossing a road segment. From the two data, the results of the analysis are as shown in Figure 4.

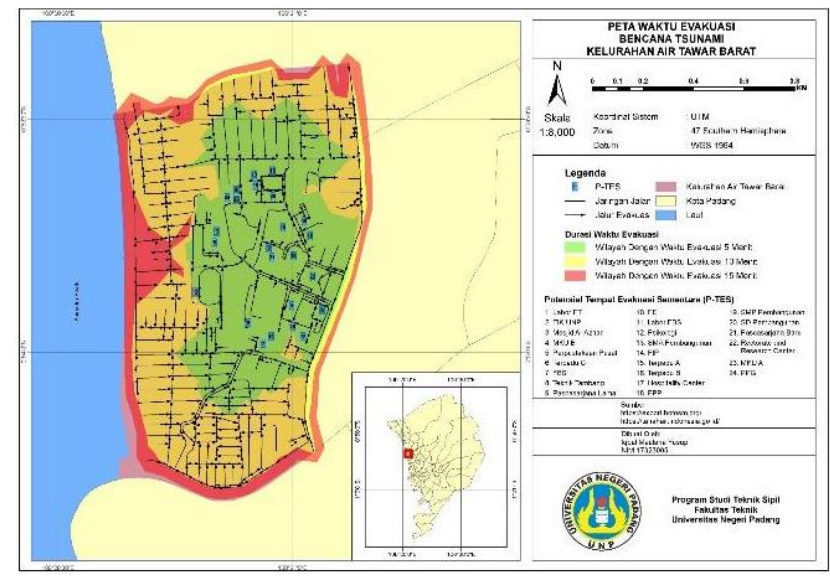

Figure 4. Evacuation Time Map Results of Analysis

\section{DISCUSSION}

Based on the Figure 4, the evacuation carried out was less effective so that several alternatives were carried out to make the evacuation more effective. As shown in Figure 5.

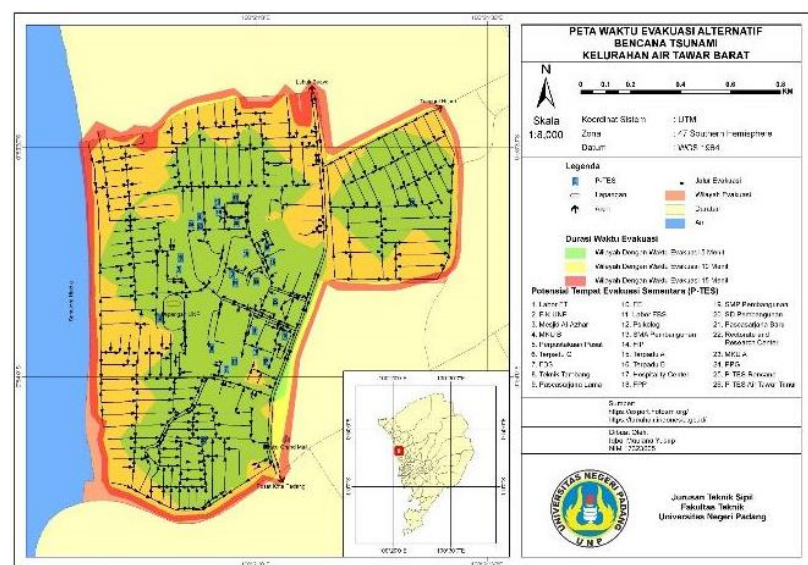

Figure 5. Map of Alternative Evacuation Time

\section{A. Alternatives 1}

Make access roads for people around Jalan Gajah to get to P-TES faster. The access roads can be made at Jalan Gajah 3, 4, 5, 6, 7 and 8. The results of the analysis before and after the alternative can be seen in Figure 6 and Figure 7.
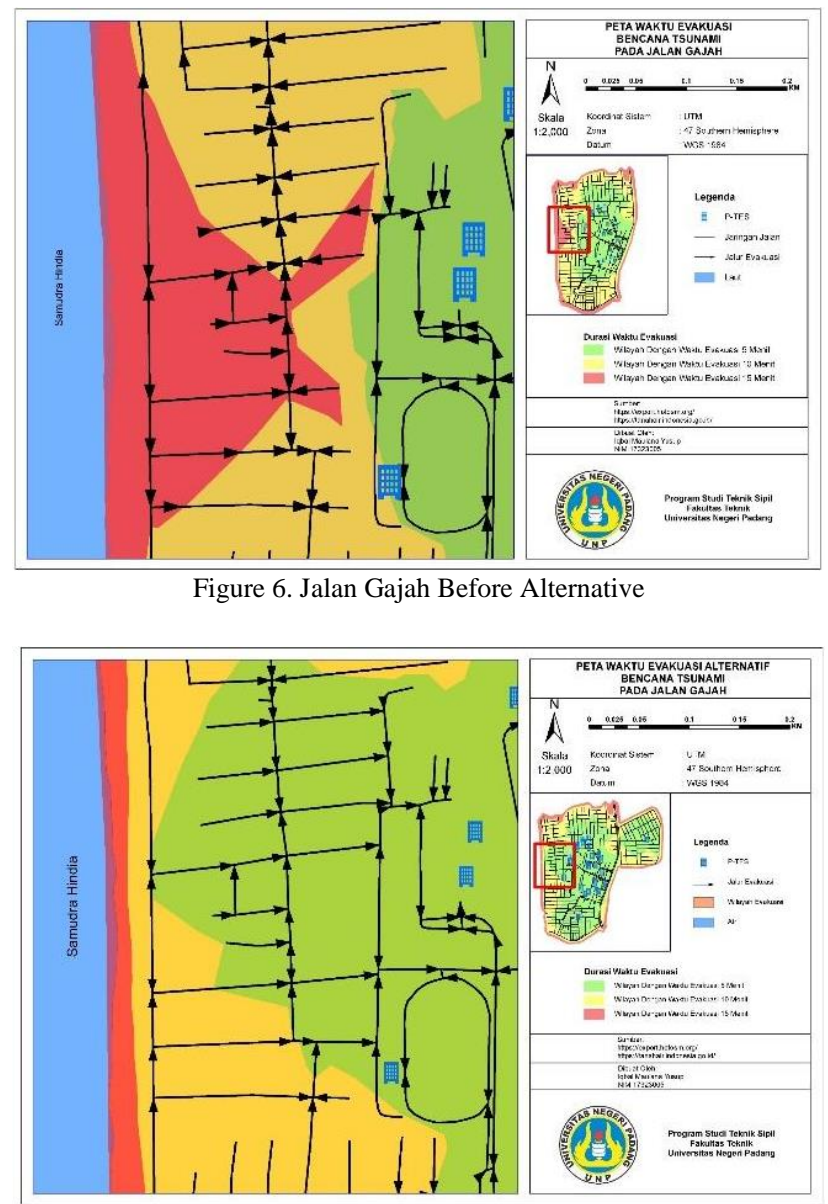

Figure 7. Jalan Gajah After Alternative carried out.

\section{B. Alternative 2}

Making P-TES in the Parking Lot of the Air Tawar Health Center to help the community around the river mouth to evacuate closer and faster than having to go 
to the P-TES located on the UNP Campus. The results of the analysis before and after the alternative can be seen in Figure 8 and Figure 9.

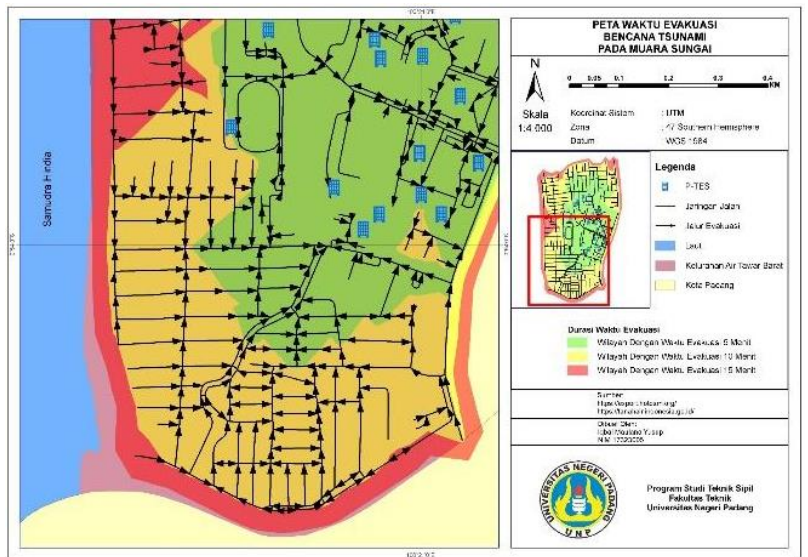

Figure 8. Around the Puskesmas Before Alternatives were carried out

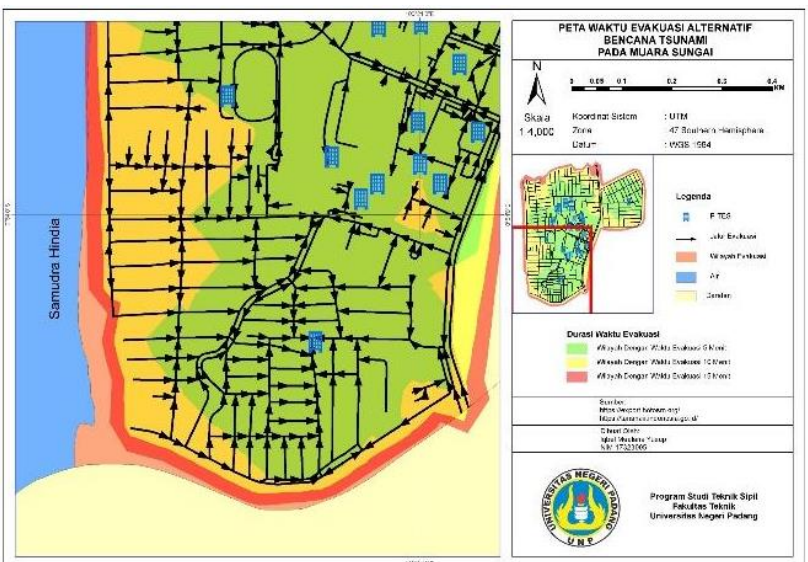

Figure 9. Around the Puskesmas After the Alternatives were carried out

\section{Alternative 3}

Directing the community around the North Padang Police Sector to evacuate to P-TES located on Jalan Polonia, Air Tawar Timur Village so as not to go to P-TES which located on the UNP Campus whose direction makes the surrounding community approach the coastline. The results of the analysis before and after alternatives can be seen in Figure 10.

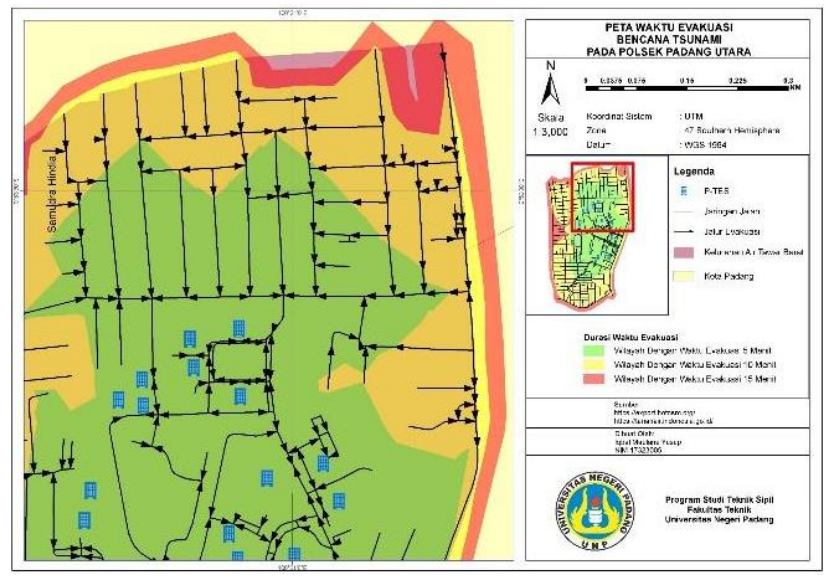

Figure 10. About Police Padang Utara Before Alternatives

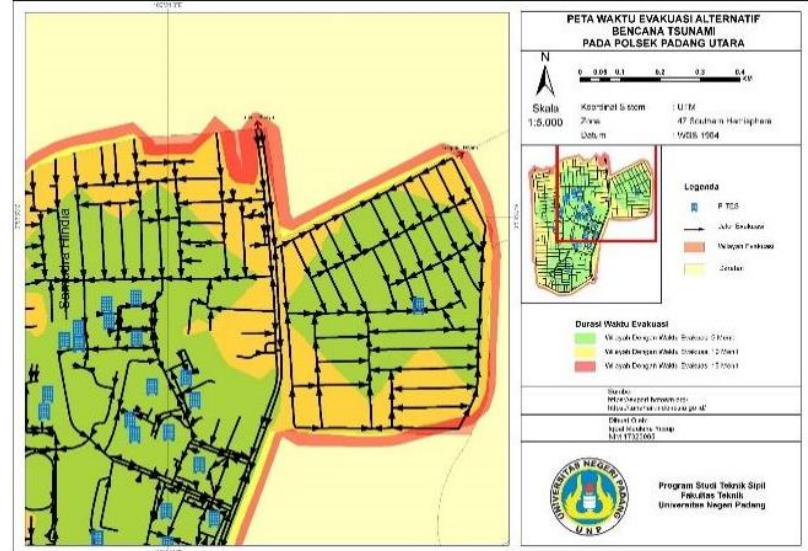

Figure 11. After Neighborhood Police carried Padang Utara Alternative

\section{Evacuation Line Comparison of the results of GIS with Paths Government Evacuation}

According to Government Area Padang No. 4 of 2012 and 2010 Tsunami Evacuation Map, the people of Air Tawar Barat Village can evacuate using the route that has been determined in sector 3 and can be seen in Figure 12.

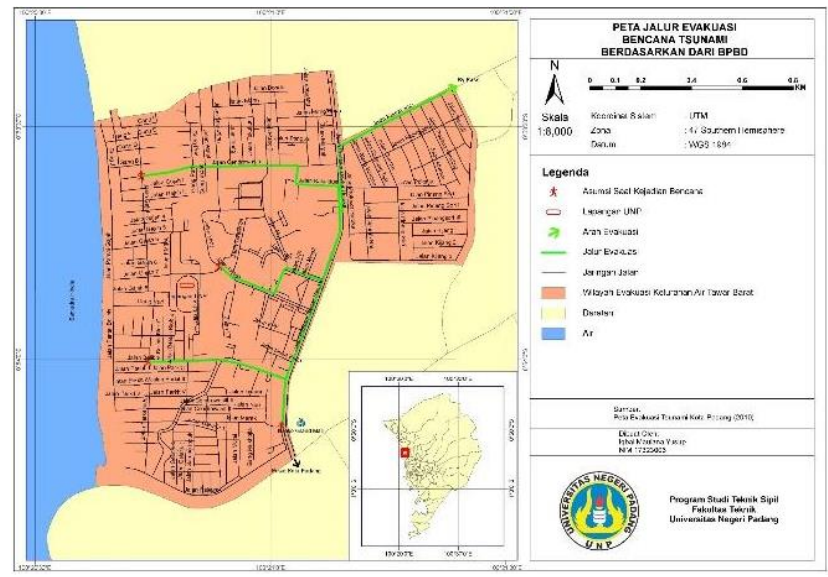

Figure 12. Map of Evacuation Paths from BPBD

Based on the map, the evacuation routes used made by the government is less effective because the distance that must be traveled is quite far, which is 3$5 \mathrm{~km}$, while the arrival time of the tsunami occurs within 30 minutes. In addition, the map is not informative because it does not show the location of the P-TES and only directs it to outside the tsunami hazard zone, and is not specific in showing the purpose of evacuation and gathering places. While the map from the GIS analysis is more informative because there is a P-TES as the direction of the evacuation destination and the route used is more likely to be taken because the distance is quite short.

The making of the route using this GIS is in accordance with the requirements of the evacuation route as stated in SNI 7766:2012, with the conclusion that the evacuation route that is made must stay away 
from the coastline, sloping areas and high places that are too far away must be made a temporary safe area and choose the shortest route. Evacuation map from the results of GIS analysis can be seen in Figure 13.

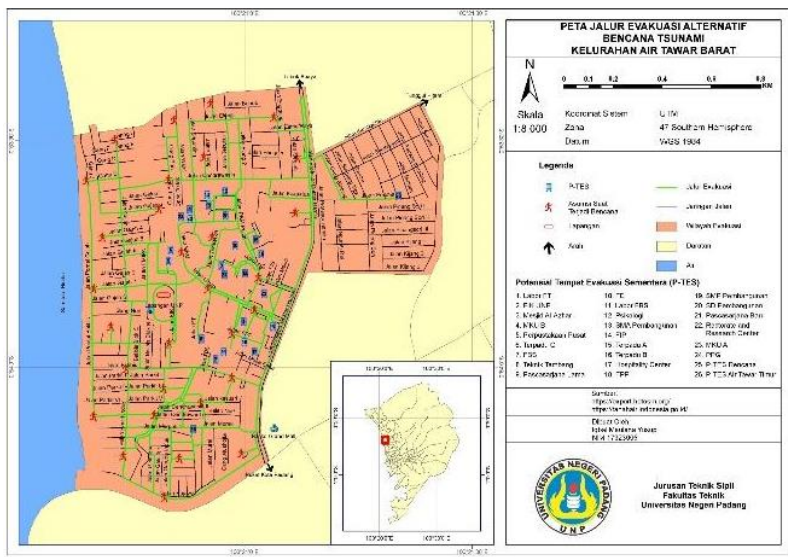

Figure 13. Map of Evacuation Paths Results of GIS Analysis

\section{CONCLUSION}

Based on the research that has been done, the following conclusions can be drawn:

1. There are 26 P-TES buildings that can be used by the people of Air Tawar Barat Village. Of which 24 are located in the Padang State University (UNP) area, 1 is in the Air Tawar Timur Village and the remaining 1 is a P-TES which is proposed to be built in the parking lot of the Air Tawar Health Center.

2. All communities in Air Tawar Barat Village can evacuate to P-TES within 10 minutes. This can happen if 26 P-TES and alternative routes can be used, so this is sufficient time as the tsunami arrival time is estimated to be less than 30 minutes.

3. The evacuation map resulting from the GIS analysis is more effective because the route used has a distance that is more likely to be taken by the people of Air Tawar Barat Village compared to the government evacuation map that goes to the tsunami safe zone which is $3-5 \mathrm{~km}$ away and must be traversed in less than 30 minutes. minute.

\section{REFERENCES}

Alhadi, Z. (2014). Kesiapan Jalur Dan Lokasi Evakuasi Publik Menghadapi Resiko Bencana Gempa Dan Tsunami Di Kota Padang (Studi Manajemen Bencana). Humanus, 13(1), 35. Https://Doi.Org/10.24036/Jh.V13i1.4095

Anam, K., Mutholib, A., Setiyawan, F., Andini, B. A., \& Sefniwati, S. (2018). Kesiapan Institusi Lokal Dalam Menghadapi Bencana Tsunami: Studi
Kasus Kelurahan Air Manis Dan Kelurahan Purus, Kota Padang. Jurnal Wilayah Dan Lingkungan, 6(1), 15 Https://Doi.Org/10.14710/Jwl.6.1.15-29

Andreas, L. O., Andayono, T., Oktaviani, Oktaviani, Zola, P., \& Zuwida, N. (2020). Sosialisasi Pemilihan Jenis Pondasi Bangunan Pada Daerah Berpotensi Bencana Di Kecamatan Alam Pauah Duo Kabupaten Solok Selatan. Cived (Journal Of Civil Engineering And Vocational Education), 7(2), 80-84. Https://Doi.Org/10.24036/Cived.V7i2.107183

Ashar, F., Amaratunga, D., \& Haigh, R. (2018). Tsunami Evacuation Routes Using Network Analysis: A Case Study In Padang. Procedia Engineering, 212, 109-116. Https://Doi.Org/10.1016/J.Proeng.2018.01.015

Kurniawan, A. A., Sutikno, S., Dosen, R., \& Sipil, J. T. (2014). Evaluasi Kapasitas Shelter Evakuasi Untuk Bencana Tsunami Di Kota Padang Berbasis Sistem Imformasi Geografis (Sig). Jurnal Online Mahasiswa (Jom) Bidang Teknik Dan Sains, 1(1), 1-9. Https://Jom.Unri.Ac.Id/Index.Php/Jomfteknik/ Article/View/3702

Oktiari, D., \& Manurung, S. (2010). Model Geospasial Potensi Kerentanan Tsunami Kota Padang. Jurnal Meteorologi Dan Geofisika, 11(2). Https://Doi.Org/10.31172/Jmg.V11i2.73

Prima, F. K., Gusmareta, Y., Abdullah, R., Rifwan, F., \& Zola, P. (2020). Edukasi Konsep Tagana (Tanggap Siap Bencana) Untuk Anak Usia Sekolah Di Daerah Rawan Bencana Kabupaten Solok Selatan Sumatera Barat. Cived (Journal Of Civil Engineering And Vocational Education), $\quad 7(2), \quad 58-62$. Https://Doi.Org/10.24036/Cived.V7i2.107184

Rifwan, F., Purnawan, P., \& Zola, P. (2019). Preferensi Masyarakat Melakukan Evakuasi Jika Terjadi Bencana Tsunami Di Kota Padang. Andalas Civ. Eng. Conf, 933-944.

Schlurmann, T., Kongko, W., Goseberg, N., Natawidjaja, D. H., \& Sieh, K. (2011). NearField Tsunami Hazard Map Padang, West Sumatra: Utilizing High Resolution Geospatial Data And Reseasonable Source Scenarios. Coastal Engineering Proceedings, 1(32), 26. Https://Doi.Org/10.9753/Icce.V32.Managemen t.26 
Suryani, R., Mutia, E., Ellida, D., \& Lydia, N. (2020). Evaluasi Rute Evakuasi Tsunami Kecamatan Padang Barat Kota Padang Menggunakan Qgis. Jurnal Media Teknik Sipil Samudra, 1(1), 2631.

Https://Ejurnalunsam.Id/Index.Php/Jmtss/Artic le/View/2863

Syam, A., \& Syam, A. (2016). Kelayakan Jalur Evakuasi Tsunami Di Kecematan Padang Utara Kota Padang. Jurnal Kepemimpinan Dan Pengurusan Sekolah, 1(1), 11-22. Https://Doi.Org/10.34125/Kp.V1i1.3

Takabatake, T., Shibayama, T., Esteban, M., Ishii, H., \& Hamano, G. (2017). Simulated Tsunami Evacuation Behavior Of Local Residents And Visitors In Kamakura, Japan. International Journal Of Disaster Risk Reduction, 23, 1-14. Https://Doi.Org/10.1016/J.Ijdrr.2017.04.003

Badan Pusat Statistik (BPS). (2020). Kecamatan Padang Utara Dalam Aangka 2020.

Peraturan Daerah Kota Padang Nomor 4 Tahun 2012. (2012). Rencana Tata Ruang Wilayah Kota Padang Tahun 2010-2030. Peratur. Drh. Kota Padang, 44. Https://Jdih.Padang.Go.Id/PoContent/Uploads/244. Perda No. 4 Tahun 2012 .Pdf. 